DOI: 10.17707/AgricultForest.63.1.21

\author{
Vera ĐEKIĆ, Vera POPOVIĆ, \\ Snežana BRANKOVIĆ, Dragan TERZIĆ, Nenad ĐURIĆ
}

\title{
GRAIN YIELD AND YIELD COMPONENTS OF WINTER BARLEY
}

\begin{abstract}
SUMMARY
The interaction of genotype $\mathrm{x}$ environment on yield and 1000 grain weight and test weight at four KG cultivars of barley (Rekord, Jagodinac, Maksa and Grand) was researched in this paper. The experiment was established on the experimental field of the Small Grains Center in Kragujevac (Serbia) during two growing seasons. The highest grains yield per area unit had, on an average, Maksa cultivar (4.935 t/ha). Average grains yield observed in the two-year period was the highest at Maksa cultivar, while the lowest yield was obtained by Jagodinac cultivar (3.882 t/ha). During the both years of investigation the highest average value of test weight achieved the Rekord cultivar $(72.14 \mathrm{~kg} / \mathrm{hl}$ and 73.22 $\mathrm{kg} / \mathrm{hl}$ ). The largest two-year average value of test weight was found in the cultivar Rekord (72.68 kg/hl), and lowest in cultivar Grand $(65.69 \mathrm{~kg} / \mathrm{hl})$. During the both years of investigation the highest average value of 1000 grain weight achieved the Maksa cultivar (49.62 g and $51.86 \mathrm{~g}$ ). The highest average 1000 grain weight was determined for cultivar Maksa (50.74 g). During 2010/2011, statistically significantly higher grain yield per area unit as well as 1000 grain weight was achieved, compared with 2009/2010. Investigations on genotype and environment interaction present the basis for further refinement and barley zoning.
\end{abstract}

Keywords: cultivar, grain yield, yield components, winter barley

\section{INTRODUCTION}

Agronomic cultivar value depends not only on its genetic potential for yield, but also on its ability to achieve genetic potential under different conditions of production (Mladenović et al., 2009, Đekić et al., 2012.a). Barley cultivars that were in production until the end of the eighties were characterized by the lower yields, good technological quality and higher stem sensitive on lodging. Due to lower resistance on lodging, that cultivars were grown at modest soils and therefore they had lower yields (Đekić et al., 2012.b). New varieties are characterized by good technological quality, better resistance on lodging and diseases, shorter stem and more efficient assimilates usage (Pržulj et al., 2004,

\footnotetext{
${ }^{1}$ Vera Đekić (corresponding author: verarajicic@yahoo.com), Small Grains Research Centre, Save Kovacevica 31, Kragujevac, SERBIA; Vera Popović, Institute of Field and Vegetable Crops Maxim Gorky St. 30, Novi Sad, SERBIA; Snežana Branković, University of Kragujevac, Faculty of Science, Institute of Biology and Ecology, 34000 Kragujevac, SERBIA; Dragan TERZIĆ, Institute for forage crops, Globoder bb, Kruševac, SERBIA; Nenad Đurić, Univerzity John Naisbitt, Belgrade, Faculty of Biofarming, Backa Topola, SERBIA

Notes: The authors declare that they have no conflicts of interest. Authorship Form signed online.
} 
2014). Yield is largely dependent on the genetic potential, which could be defined as yield of variety which was grown in conditions on which it had been adapted, with adequately amounts of water and nutrients and efficient control of pests, diseases, weeds and other stresses (Đekić et al., 2011). Grain yield is a value, which is not only genetically determined but also dependent to a high degree on the growing conditions (Popović et al., 2011, Sabaghnia at al., 2013, Chamurliyski et al., 2015). Yields considerably vary primarily as a result of agroecological conditions during the growing season (Đekić et al., 2014). Experimental research needs to be carried out over multiple environment trials in order to identify and analyse the major factors that are responsible for genotype adaptation and final selection (Popovic at al., 2011, Mirosavljevic et al 2014; Kendal, E and Dogan, Y. (2015), Dogan et al 2016). Malting barley is expected to have 1000 grain weight of 40 and $46 \mathrm{~g}$ and test weight of 68 to 75 $\mathrm{kg} / \mathrm{hl}$ (Paunović et al., 2006).

Barley is in the usage as an important component of beer and malt production, important and quality component in animal feeding, partially in human nutrition as well as a component in processing industry (Đekić et al., 2012.a). As a top-quality forage crop plant, barley is used as fodder unit in meals balancing in animal feed (Đekić et al., 2010).

The aim of this study was determination of the cultivars and ecological environmental factors influence on differences in stability and adaptability of cultivars regard the grain yield, 1000 grains weight and test weight of tested winter barley cultivars, as well as specificity cultivars exploring regard growing seasons conditions.

\section{Experimental design}

\section{MATERIAL AND METHODS}

During the 2009/2010 and 2010/2011 growing seasons, four cultivars of winter barley (Rekord, Jagodinac, Maksa and Grand), cultivated at the Center for Small Grains in Kragujevac (Serbia) were investigated.

Experiments have been conducted in randomized block systems, with a plot size of $10 \mathrm{~m}^{2}(2 \mathrm{~m} \times 5 \mathrm{~m})$ in two replicates. The usual techniques for barley production were applied, and it was done in the optimum sowing time in late October. $400 \mathrm{~kg} / \mathrm{ha}$ of fertilizer NPK 15:15:15 was added in the fall on the investigated plots, while during the spring fertilization, $300 \mathrm{~kg} / \mathrm{ha}$ (KAN) was supplemented. The following properties were analyzed: grain yield $(\mathrm{t} / \mathrm{ha})$, test weight $(\mathrm{kg} / \mathrm{hl})$ and 1000 grain weight $(\mathrm{g})$.

\section{Meteorological conditions}

Kragujevac area is characterized by a moderate continental climate, which general feature is uneven distribution of rainfall by months.

Data in Graph 1 and 2 for the investigated period (2009-2011) clearly indicate that the years in which the researches were conducted differed from the typical multi-year average for Kragujevac region, regarding the meteorological conditions. 


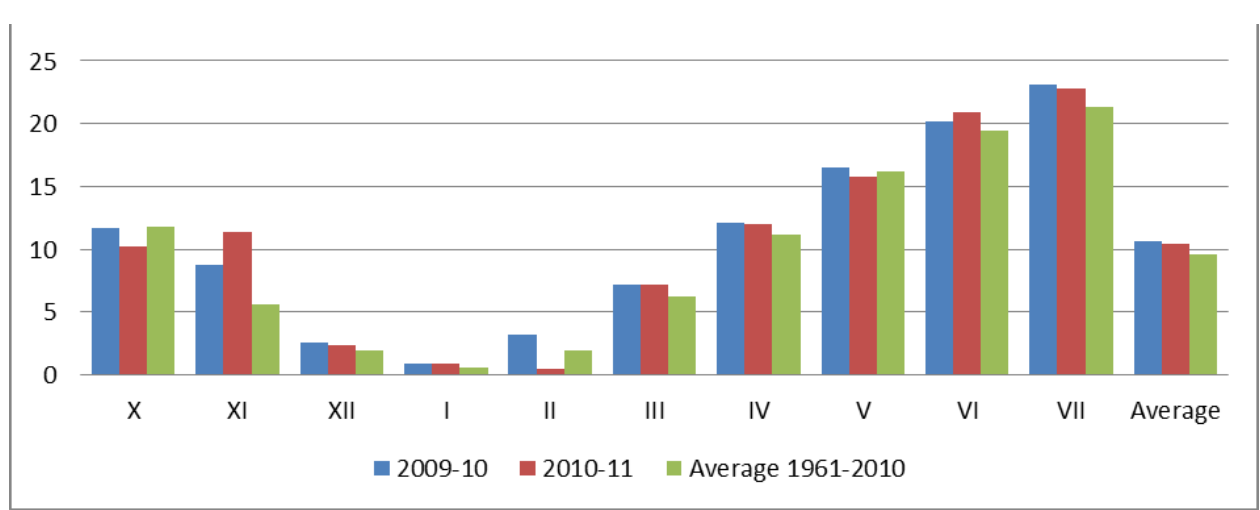

Graph. 1. Mean monthly air temperature, ${ }^{\circ} \mathrm{C}$, Kragujevac, Serbia

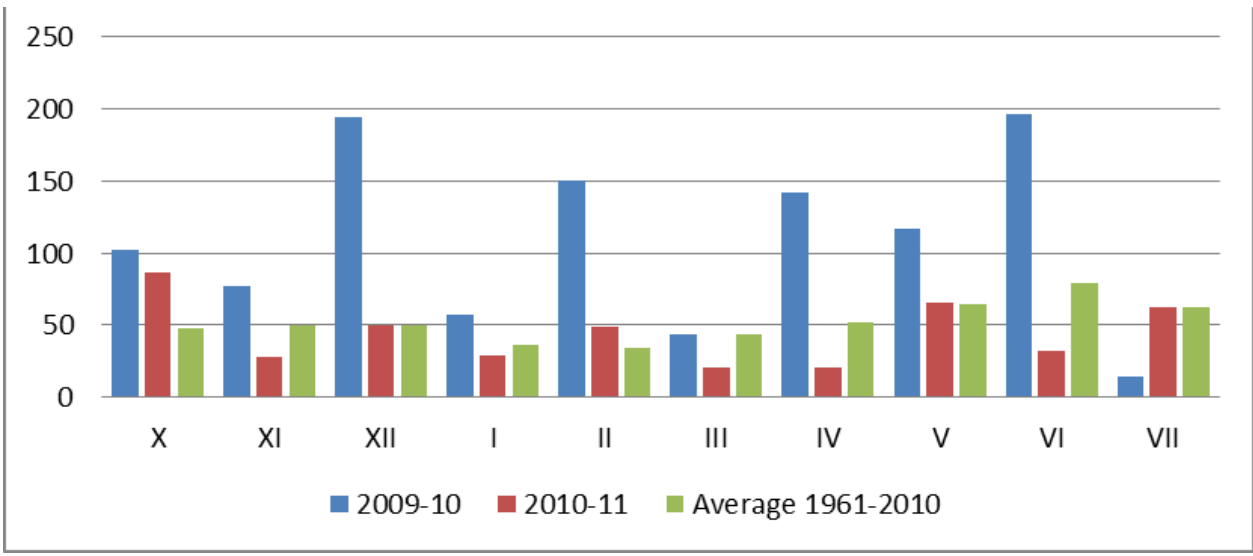

Graph. 2. Total monthly precipitation, mm, Kragujevac, Serbia

The average air temperature in $2009 / 2010$ was higher by $1.01{ }^{\circ} \mathrm{C}$ and $2010 / 2011$ was higher by $0.79^{\circ} \mathrm{C}$. The sum of rainfall precipitation in $2009 / 10$ was higher by $576.2 \mathrm{~mm}$, where the sum of rainfall in 2010/2011 was $75.1 \mathrm{~mm}$ lower than the average of many years and with a very uneven distribution of precipitation per months. Spring months April and May in 2009/2010 were surplus of precipitation, what affected unfavorable on the crops. During the April in 2009/2010 it was $142.2 \mathrm{~mm}$ of rainfall, what was $90.7 \mathrm{~mm}$ more compared with the perennial average. During the month of June in 2009/2010 it was $196.7 \mathrm{~mm}$ of rainfall, what was $117.4 \mathrm{~mm}$ more compared with the perennial average. Regard the high importance of sufficient rainfall amounts during the spring months, particularly May for small grains production, the distribution and amount of rainfall over the growing season 2010/2011 were considerably more favorable, what resulted with increment of yields during that year, graph. 1 and 2 . Apart from the rainfall deficiency during the spring months and the non-uniform distribution of rainfall across months, an increasing in average air temperatures was also observed. 
Based on the fact that sufficient amounts of rainfall in these months are very important for the successful production of cereal crops it can be concluded that the 2009/2010 year in which the researches were conducted were not favorable for the barley growing.

\section{Soil and weather conditions}

Before the commencement of the experiment soil samples were taken from the sample surface and the chemical analysis of soil was performed. On the basis of obtained results it was revealed that the soil belongs to the smonitza type, with relatively high clay content, and unfavorable physical properties. The humus content in the surface layer of soil was low $(2.38-2.64 \%)$, and a substitution and total hydrolytic acidity were quite high $\left(\mathrm{pH} \mathrm{H}_{2} \mathrm{O}=5.99, \mathrm{KCl}=4.56\right)$. The soil was medium provided with total nitrogen $(0,11-0,13 \% \mathrm{~N})$ and easily accessible potassium (10-14 mg/100 g soil $\mathrm{K}_{2} \mathrm{O}$ ), while the available phosphorus content was low (under $10 \mathrm{mg} / 100 \mathrm{~g}$ of soil $\mathrm{P}_{2} \mathrm{O}_{5}$ ).

\section{Statistical Analysis}

On the basis of achieved research results the usual variational statistical indicators were calculated: average values, error of the mean (arithmetic) and standard deviation. Statistical analysis was made in the module Analyst Program SAS/STAT (SAS Institute, 2000).

\section{RESULTS AND DISCUSSION}

Average values of yield ( $\mathrm{t} / \mathrm{ha})$, test weight $(\mathrm{kg} / \mathrm{hl})$ and 1000 grain weight (g) at investigated Kragujevac's winter barley cultivars grown at the Center for Small Grains in Kragujevac during two growing seasons, 2009/2010 and 2010/2011, are presented in the Tab. 1.

Table 1. Average values of investigated barley cultivars characteristics

\begin{tabular}{|c|c|c|c|c|c|c|c|c|c|c|}
\hline \multirow{2}{*}{ Traits } & \multirow{2}{*}{ Cultivar } & \multicolumn{3}{|c|}{$2009 / 2010$} & \multicolumn{3}{|c|}{$2010 / 2011$} & \multicolumn{3}{|c|}{ Average } \\
\hline & & $\mathrm{x}$ & $\mathrm{S}$ & $\mathrm{Sx}$ & $\mathrm{x}$ & $\mathrm{S}$ & $\mathrm{Sx}$ & $\mathrm{x}$ & $\mathrm{S}$ & $\mathrm{Sx}$ \\
\hline \multirow{4}{*}{$\begin{array}{l}\text { Grain } \\
\text { yield } \\
\text { (tha) }\end{array}$} & Rekord & 3.200 & 0.366 & .163 & 5.666 & 0.419 & 0.187 & .433 & 1.351 & 0.427 \\
\hline & Jago & 642 & 222 & 099 & 5.122 & 264 & 18 & 32 & 27 & 2 \\
\hline & Mak & 3.930 & 0.190 & 085 & 5.940 & 0.401 & $1 / 9$ & 35 & 1.100 & .7 \\
\hline & Gran & 3.444 & 0.138 & 062 & 5.554 & 0.263 & 0.117 & 4.499 & 1.130 & 0.357 \\
\hline \multirow{4}{*}{$\begin{array}{c}\text { Test } \\
\text { weight } \\
(\mathrm{kg} / \mathrm{hl})\end{array}$} & Rekord & 72.14 & 0.948 & 0.424 & 73.22 & 0.634 & 0.283 & 72.68 & 0.950 & 0.300 \\
\hline & Jagodinac & 70.27 & 2.112 & 0.944 & 71.05 & 1.149 & 0.514 & 70.66 & 1.655 & 0.523 \\
\hline & Maksa & 70.71 & 1.183 & 0.529 & 71.72 & 0.421 & 0.188 & 71.21 & 0.992 & 0.314 \\
\hline & Gral & 64.17 & 2.528 & 1.131 & 67.20 & 0.469 & 0.210 & 65.68 & 2.343 & 0.741 \\
\hline \multirow{4}{*}{$\begin{array}{c}1000 \\
\text { grain } \\
\text { weight } \\
\text { (g) }\end{array}$} & Rekc & 48.18 & 1.310 & 0.586 & 50.66 & 2.019 & 0.903 & 49.42 & 2.070 & 0.654 \\
\hline & Jagc & 41.52 & 0.958 & 0.428 & 49.70 & 0.678 & 0.303 & 45.61 & 4.382 & 1.386 \\
\hline & $\mathrm{Mak}$ & 49.62 & 0.444 & 198 & 51.86 & 1.816 & 0.812 & 50.74 & 1.717 & 0.543 \\
\hline & Grand & 40.36 & 0.654 & 0.293 & 40.40 & 0.894 & 0.400 & 40.38 & 0.739 & 0.23 \\
\hline
\end{tabular}

During the first year of investigations, cultivar Maksa achieved the highest grains yield (3.930 t/ha), while the lowest yield was at Jagodinac cultivar 
(2.642 t/ha). During the second year of investigations (2010/2011), the yield of Maksa cultivar was the highest with $5.940 \mathrm{t} / \mathrm{ha}$, while the slightly lower yield was realized by Rekord and Grand cultivars (5.666 t/ha and 5.554 t/ha). Average grains yield observed in the two-year period was the highest at Maksa variety (4.935 t/ha), while the lowest yield was obtained by Jagodinac cultivar (3.882 t/ha). Considerable variation in yield depending on years of research have established Jelić et al. (2007), Đekić et al. (2011), Malešević et al. (2010) and Popović et al. (2011).

Achieved statistically significantly higher yields in 2010/2011 were, primarily, the result of heavy rainfalls and their good distribution as well as favorable air temperatures during the vegetation period (Graph 1 and 2). Đekić et al. (2014) in his research states that the air temperatures and the rainfall amount and distribution during the barley growing season have the greatest impact on high yields and grain quality.

The barley cultivar Rekord has achieved the highest test weight in both years of investigation compared to other tested barley cultivars $(72.14 \mathrm{~kg} / \mathrm{hl}$ and $73.22 \mathrm{~kg} / \mathrm{hl}$ ). The average two-year value of test weight at Rekord cultivar was $72.68 \mathrm{~kg} / \mathrm{hl}$, Maksa $71.21 \mathrm{~kg} / \mathrm{hl}$, Jagodinac $70.66 \mathrm{~kg} / \mathrm{hl}$, while the lowest average was at Grand cultivar $(65.68 \mathrm{~kg} / \mathrm{hl})$, Table 1 .

Table 2. Analysis of variance of the tested parameters (ANOVA)

\begin{tabular}{|c|c|c|c|c|}
\hline \multicolumn{5}{|c|}{ Effect of year on the traits analyzed } \\
\hline Traits & $\begin{array}{l}\text { Mean sqr } \\
\text { Effect }\end{array}$ & $\begin{array}{c}\text { Mean sqr } \\
\text { Error }\end{array}$ & $\begin{array}{c}\mathrm{F}(\mathrm{df} 1,2) \\
1,38\end{array}$ & p-level \\
\hline Grain yield $\left(\mathrm{t} \mathrm{ha}^{-1}\right)$ & 51.3702 & 0.23402 & $219.517^{* * *}$ & 0.000000 \\
\hline Test weight $\left(\mathrm{kg} \mathrm{hl}^{-1}\right)$ & 21.7563 & 9.11184 & 2.388 & 0.130582 \\
\hline 1000-grain weight $(\mathrm{g})$ & 104.6523 & 20.67320 & $5.062^{*}$ & 0.030324 \\
\hline \multicolumn{5}{|c|}{ Effect of cultivar on the traits analyzed } \\
\hline Traits & $\begin{array}{c}\text { Mean sqr } \\
\text { Effect }\end{array}$ & $\begin{array}{c}\text { Mean sqr } \\
\text { Error }\end{array}$ & $\begin{array}{c}\mathrm{F}(\mathrm{df} 1,2) \\
3,36\end{array}$ & p-level \\
\hline Grain yield $\left(\mathrm{t} \mathrm{ha}^{-1}\right)$ & 1.8663 & 1.518442 & 1.229 & 0.313291 \\
\hline Test weight $\left(\mathrm{kg} \mathrm{hl}^{-1}\right)$ & 92.3302 & 2.528208 & $36.520^{* * * *}$ & 0.000000 \\
\hline 1000-grain weight $(\mathrm{g})$ & 215.8162 & 6.744028 & $32.001^{* * *}$ & 0.000000 \\
\hline \multicolumn{5}{|c|}{ Effect of the year $x$ cultivar interaction } \\
\hline Traits & $\begin{array}{c}\text { Mean sqr } \\
\text { Effect }\end{array}$ & $\begin{array}{c}\text { Mean sqr } \\
\text { Error }\end{array}$ & $\begin{array}{c}\mathrm{F}(\mathrm{df} 1,2) \\
3,32\end{array}$ & p-level \\
\hline Grain yield $\left(\mathrm{t} \mathrm{ha}^{-1}\right)$ & 0.14639 & 0.089204 & 1.641 & 0.199369 \\
\hline Test weight $\left(\mathrm{kg} \mathrm{hl}^{-1}\right)$ & 2.72775 & 1.908625 & 1.429 & 0.252430 \\
\hline 1000-grain weight $(\mathrm{g})$ & 30.18425 & 1.486875 & $20.300^{* * *}$ & 0.000000 \\
\hline
\end{tabular}

"Statisticaly significant difference $(P<0.05){ }^{* * *}$ Statisticaly high significant difference $(P<0.01)$

Grain of investigated barley cultivars was characterized by good physical characteristics; especially regard the test weight and 1000 grain weight. Realized 
average values of these characteristics in the study were slightly higher than the values obtained by Jelić et al. (2007) and Đekić et al., (2011).

Table 2 shows the impact of year, cultivar and interaction of year $\mathrm{x}$ cultivar on yield, test weight and 1000-grain weight. The ANOVA indicated very highly significant effects of the year and grain yield $\left(\mathrm{F}_{\exp }=219.517^{* * * *}\right)$ and significant effects of the 1000 grain weight $\left(\mathrm{F}_{\mathrm{exp}}=5.062^{*}\right)$. Our results are consistent with the results Madic et al. (2009), where the authors state that the growing conditions in the observed years had a significant impact on yield. Very highly significant differences in test weight and 1000-grain weight at investigated barley were found in relation with the cultivar. The interaction of 1000-grain weight and year $\mathrm{x}$ cultivar very highly significant differences at investigated barley cultivars.

\section{CONCLUSIONS}

Based on the gain results during two-year investigation on four Kragujevac's winter barley cultivars, it can be concluded that the highest yield achieved the cultivar Maksa (4.935 t/ha). Rekord and Jagodinac cultivars have achieved satisfactory results, while the poorest results were achieved by the Grand cultivar. During 2010/2011, statistically significantly higher grain yield per area unit as well as 1000 grain weight was achieved, compared with 2009/2010. Very highly significant differences in 1000 grain weight at investigated barley cultivars were found relative to the cultivar and very significant differences at grain yield relative to environmental factors. Very highly significant influence of the interaction of 1000-grain weight and year $\mathrm{x}$ cultivar differences at investigated barley cultivars.

\section{ACKNOWLEDGEMENTS}

Investigations necessary for this papers are part of the projects: TR 31054 "Development of new cereals cultivation technologies on acid soils by usage of modern biotechnology", and TR 31022; financed by the Ministry of Education, Science and Technology Development of Republic of Serbia.

\section{REFERENCES}

Chamurliyski P., Atanasova D., Penchev E. (2015): Productivity of foreign common winter wheat cultivars (Triticum aestivum L.) under the conditions of dobrudzha region. Agriculture \& Forestry, Podgorica. Vol. 61, Issue 1: 77-83.

Dogan Y., Kendal E., Oral E. (2016): Identifying of relationship between traits and grain yield in spring barley by GGE biplot analysis. Agriculture \& Forestry, Vol. 62, 4. p: in press.

Đekić V., Staletić M., Glamočlija Đ., Branković S. (2010): Variability of yield and grain yield components of $\mathrm{KG}$ winter barley cultivars. Zbornik radova XV Savetovanja o biotehnologiji sa međunarodnim učešćem, 26-27. Mart 2010, Čačak, Vol. 16 (17), 223-226.

Đekić V., Milovanović M., Glamočlija Đ., Staletić M. (2011): Yield and components yield grain in Kragujevac of winter barley varieties. Proceedings. 46 Croatian and 6 International Symposium on Agriculture, 14-18. Februar 2011, Opatija, Croatia, 601-604. 
Đekić V., Staletić M., Milivojević J., Jelić M., Popović V. (2012.a): Parameters of spring barley grain yield. Zbornik radova XVII Savetovanja o biotehnologiji sa međunarodnim učešćem, 6-7. April 2012, Čačak, Vol. 17 (19), 53-57.

Đekić V., Milovanović M., Staletić M., Popović V., Jelić M. (2012.b): Effect of genotype and environment on winter barley quality (Hordeum vulgare L). Proceedings, XVI International Eco-Conference ${ }^{\circledR} 2012$ "Safe food", 26-29. September 2012, Novi Sad, 145-153.

Đekić V., Milovanović M., Popović V., Milivojević J., Staletić M., Jelić M., Perišić V. (2014): Effects of fertilization on yield and grain quality in winter triticale. Romanian Agricultural Research, No.31, p. 255-266, DII 2067-5720 RAR 2012255.

Jelić M., Đalović I., Savić N., Knežević D. (2007): The effect of amounts of seed and dose of nitrogen fertilizers to grain yield and quality of forage winter barley and oat. ječma. A Periodical of Scientific Research on Field and Vegetable Crops, Vol. 44, 481-486.

Kendal, E and Dogan, Y. (2015). Stability of a Candidate and Cultivars (Hordeum vulgare L) by GGE Biplot analysis of Multi-environment Yield Trials in Spring Barley. Agriculture \& Forestry, Vol. 61, Issue 4: 307-318, 2015, Podgorica, DOI: 10.17707/AgricultForest.61.4.37.

Madić M., Paunović A., Knežević D., Zečević V. (2009): Grain yield and yield components of two-row winter barley cultivars and lines. Acta Agriculturae Serbica, Vol. 14, No. 27, 17-22.

Malešević M., Glamočlija Đ., Pržulj N., Popović V., Stanković S., Živanović T., Tapanarova A. (2010): Production characteristics of different malting barley genotypes in intensive nitrogen fertilization. International Scientific Journal Genetics, ,Genetika“ Belgrade, Vol. 42, No. 2, 323-330.

Mladenović G., Kovačević N., Malešević M., Štatkić S. (2009): NS small grain seed production and marketing in the period 1998-2007. A Periodical of Scientific Research on Field and Vegetable Crops, Vol. 46, No. 2, 379-384.

Mirosavljevic, M., Przulj, N., Bocanski, N., Stanisavlievic, D., Mitrovic, B. (2014). The application of AMMI model for barley cultivars evaluation in multi-year trials. Genetika, Vol: 46, No. 2, 445-454.

Paunovic A., Madic M., Knezevic D., Djurovic D. (2006): The interdepedence of productive and technological traits in two-rowed spring barley. Acta Agriculturae Serbica, Vol. XI, No. 22, 37-43.

Popović V., Glamočlija Đ., Malešević M., Ikanović J., Dražić G., Spasić M., Stanković S. (2011): Genotype specificity in nitrogen nutrition of malting barley. Genetika. Belgrade, Vol. 43, No. 1, 197-204.

Pržulj N. (2001): Cultivar and year effect on grain filling of winter barley. Plant Breeding and Seed Science. Vol. 45, No. 2, 45-58.

Pržulj N., Momčilović V., Petrović N. (2004): Physiological basis of barley yield under near optimal and stress conditions. Plant Breeding and Seed Production, Vol. X, 14, 15-26.

Przulj, N., Momcilovic, V., Simic, J. and Mirosavljevic, M. (2014).Effect of growing season and variety on quality of spring two-rowed barley. Genetika, 46: 59-73.

Sabaghnia N., Mohammadi, M., Karimizadeh, R., 2013. Interpreting genotype x environment interaction of bread wheat genotypes using different nonparametric stability statistics. Agriculture \& Forestry, Podgorica, MNE, Vol. 59, Issue 2: 21 35 . 